\title{
Röpke and Einaudi: from the Civitas of Persons to the Idea of Europe
}

Francesco Forte*

Department of Economics and Law, University of Rome "La Sapienza", Rome, Italy;

Mediterranean University of Reggio Calabria, Reggio Calabria, Italy

Received October 10 2017; Accepted January 92018

Abstract: The first part of the paper deals with the so-called liberal Third Way of Röpke and Einaudi, which has, at its center, the person and civitas umana. Subsidiarity principle, market, and conform public interventions define the role and limits of public powers. The second part presents eight main indicators of the divergent performance of the four main Economic and Monetary Union (EMU) countries. The third part deals with the incompleteness of the institutional construct of the European Union (EU) and the EMU that are clubs of sovereign states in the light of Einaudi's and Röpke's ideas. Suggestion about corrections of fiscal compact, banking regulations, and "bail in" and about a closer cooperation between European Central Bank (ECB) monetary policy and European budget and EU fiscal policy concludes the paper.

Keywords: Luigi Einaudi • Wilhelm Röpke • Civitas • Social market economy • Europe

\section{Röpke's and Einaudi's liberalism centered on the civitas of persons}

\subsection{Ordo, civil economy, and Einaudi's and Röpke's good government}

As indicated in the title of this conference paper, there are two ethical-anthropological approaches to the economics and the sociology of the welfare of human communities and the global society: the German social market economy and the Italian civil economy. The former has clear roots: those of the Ordo school of Freiburg of Eucken and Böhm (Peacock and Wilgerodt 1989a,b; Goldschmidt and Wohlgemuth 2008a,b; Böhm et al. 1936; Forte and Felice 2012, 2016; Aßländer and Ulrich 2009; Aßländer 2009). Their competitive market economy and political democratic order are characterized by two basic principles: 1) individuals are persons, i.e., they have an intrinsic value "in se"; 2) private law dominates public law and not vice versa. A constitution, i.e., an Ordo with basic rules, must assure the functioning of the model. This Ordo is a construct that follows from the human nature, i.e., it is a natural order (Eucken 1948, pp.56-90; Eucken 1952; Vanberg 2004; Goldschmidt 2009).

To complete this construct, two sections were created: one section was created by Müller-Armack (Müller-Armack 1946, 1976; Erhard 1957; Nicholls 1994; Goldschmidt 2004; Dietzfelbinger 2009), who emphasized the components of justice, and the other one was created by Röpke, who stressed the relevance of "humane" issues of the "civitas" (Röpke 1942, 1944, 1950; Einaudi 1942; Forte and Felice 2016; Forte 2001, 2009, pp.223-251; Felice 2014, 2016; Röpke 2016).

The Italian "civil economy" is a conception of a free order with some important points in common with Ordo (Bruni and Pelligra 2002; Bruni and Zamagni 2004; Felice 2013). The welfare of the society is not an algebraic sum: values of individual freedom and 
dignity have a lexicographic priority, i.e., the sentiment of love involves important redistributive interventions for the less favored and implies a priority of redistributive justice (Villari 1959; Pii 1984; Venturi 1969; Di Battista 1990; Bruni 2009).

Another stream of Italian civil economy makes reference to Rosmini's (1994, 1993-1996) liberal thought in which, at the center, there is a free person, who pursues values that go beyond the utility and include the compassion and love for others; however, it is incomplete without the protection of individual property rights, which are essential for his/her freedom. The government is merely subsidiary to the persons and to their private communities and must follow the same principles (Rosmini 1993; Rosmini 1994; Mingardi 2004; Krienke 2014).

The theory of the good government of the city and nation like the home of the family goes back to the Italian tradition of the "good government of the city" of Renaissance, which was started in the late middle age. The experienced government must follow the rules of "good government" - in a way similar to family-life, in which the members coexist freely and cooperate spontaneously (Alberti 1432-34; Sacchi 1461, 1471; Carafa 1470-74).

Einaudi's political economy (Einaudi 1949, 1954, 1962; Forte 2009; Heritier and Silvestri 2012, pp.57-100; Silvestri 2012) also belongs to the tradition of Civil Economy (Forte 2012, pp.13-34). On the cover of the book II Buon Governo - the book of collected papers - which was published when Einaudi was the president of the Italian Republic, the famous painting "The effects of the good and of the bad Government" of about 1338 of Ambrogio Lorenzetti in the palace of the Municipality of Siena can be seen. For Einaudi, each person is "the lord" of his/her own human capital and material and immaterial properties. L'uomo signore of Einaudi, as in the Rerum Novarum encyclical (Forte et al. 2017, pp.135-166), differs from the animals because he/she owns a property, even minimal or/and immaterial, which he/she has created with his/her labor and savings with free choices under the rules of the government, to which he/she concurs with the other common members. The good government of the city must apply the rules of the good government of the family. The inner reason is that the public economy is subsidiary to the market economy and, therefore, to perform its functions properly it must follow the principles and rules according to the welfare of the family. Keynes's idea that the private virtues are public vices is unacceptable in Einaudi's "civil economics liberal perspective".

Röpke's civitas humana, like Einaudi's civitas with good government, is an "order" conforming to the needs of men and women, which cannot be merely economic, because they are not mere economic individuals, but they are persons. The communities from which this order must proceed are, primarily, natural communities of free persons. This conception implies individual freedom and the diffusion of property under the humane-divine concept of men and women as masters of their small universe, created by their labor, which reflects the intimate need of expressing, by their labor and its fruits, the creativity of god.

\subsection{Subsidiarity principle, interventions conform to the free competitive market, critical point}

The divine civitas is the dream of Einaudi for the human civitas (Tomatis 2011), beyond the economic laws of the historical capitalism (Einaudi 1942, pp.185-224). Röpke in his book Beyond the demand and supply wrote against the "inhumane" mass capitalism - including its anthropological concept of social organization and social order; both were perceived here as the big dominating system - flattening the rest of the world (Forte 2009, pp.223-238).

For both Röpke and Einaudi, the anthropological view of the horizontal priority of the persons and the private house on the public house and the consequent primacy of the bottom-up order is not a mere normative approach, as it is - primarily - a positive approach deriving from the observation of human nature and facts.

One of the main reasons why, for Röpke and Einaudi, the positive observation of human nature suggests a preference for the horizontal and bottom-up structures with subsidiarity principles is that the persons have a limited rationality and limited information capability. The human nature is imperfect even from the point of view of the respect of the rules and behaviors, in which the persons believe that it is appropriate for themselves, because often their will is weaker than their reason. The technocracy may frequently make mistakes and undertake opportunistic behaviors. Both Röpke's and Einaudi's free market conceptions following their anthropological conception imply a competitive structure with a process of trial and errors, which are sharply different from the free market monopolistic structure, which has often characterized as the "historical capitalism" and the current one, with its technocracy. For this reason, the freedom requires the protection by rules hindering or limiting the powers of the monopolies and by interventions to the market which assure an open society and restore the competition forces. Public interventions to keep a free market competition and a humane civitas intact (based on a bottom-up democracy) must be in line with the competitive market and must be subsidiarity to it. Einaudi borrowed the general principle from Röpke that political economy based on public interventions must be conformed to the logic of the competitive free market (Röpke 1936, 1942; 
Einaudi 1937, pp.277-289; Einaudi 1942, pp.185-224). This principle, anyway, had received an important application in the public finance sector by Italian school of science of finance with taxes as fiscal prices of public service, of which Einaudi was a leading figure.

Einaudi added the "critical point" (Forte 1999, Vaudano 1999) to the two Röpkekian principles of conform interventions and subsidiarity, after which the costs of its application exceed the benefits that it may give. The critical point criterion requires that the "liberalism of rules" makes moderate use of rules; and the rules must be simple, clear, certain, and as stable as possible. Competition has a critical point after which it becomes excessive and obsessive. Subsidiarity also has critical points, as its application may make the structure of the public sector and the third sector too complex.

\section{Recovery with different speeds and dualistic performances in the euro area}

A diversity of performances is taking place in the core of Europe and the euro area, as the economic and financial data and forecast of the European Commission are summarized in Table 1.

Observing the indicators clearly emerges a dualism among the main countries of the euro club, with Germany, with superior performances, as for the rates of gross domestic product (GDP), the investments, the inflation rate, labor productivity, budget balance, debt burden, and the current balance of payment deficit or surplus.

Likely, in European Union (EU) and Economic and Monetary Union (EMU), there are structural imperfections and political economic inadequacies. Therefore, Röpke and Einaudi propose new ideas.

\section{Reforming the EU and EMU as clubs of sovereign states: Röpke and Einaudi's ideas}

\subsection{The incompleteness of the European institutional construct and the misunderstandings about its basic principles}

The institutional construct of the EU - as a club of sovereign states ${ }^{1}-$ in its broad foundations fits with the model

1 James Buchanan's seminal theory of club goods and governments as clubs offering a single public good or a set of public goods to their of the civitas humana of Röpke in his books (Röpke 1953; Röpke 1958/2009; Röpke 1966) and that of the "good government" of Einaudi, for an EU, as presented, particularly in his works of the Swiss period (Einaudi's basic model for the EU is given in Einaudi [1948] and Forte [2009, pp.303-319]).

For the economy, these concepts follow the theoretical model of competitive unique free markets; for the public economy, for both the member states and the EU, they follow the two principles of subsidiarity and marketconform Government interventions. However, Röpke's and Einaudi's architecture of a European free market economy and of EU (and EMU) as market-conform club governments are also incomplete. The rules and policies suggested by the authors rather reveal serious faults.

According to Article 119 of the current EU constitution, "the activities of the Member States and the Union shall include an economic policy based on the close coordination of Member States' economic policies, on the internal market and on the definition of common objectives, and conducted in accordance with the principle of an open market economy with free competition." However, in the EU, there is not a unique competitive labor market, characterized by decentralization and freedom of contracting, at the single business level, under the respect of the basic rights of the workers. While there is, in principle, the free movement of labor through the various member countries, each country has its own labor market institutions, which are more or less liberalized. The high level of unemployment in the EMU area and in most member countries, with the exception of Germany, is a clear demonstration of the effect of its vertical monopolization. In Italy, there is now a centralistic, vertical labor legislation, named as "Jobs Act," which is much less liberal than the former laws. EU authorities seem to have considered this new Italian "Job Act" as reform conforming to the competitive market principles, merely because the firms have the right to fire the workers for both economic and disciplinary reasons. However, this right has, as counterpart, the abolition of any freedom of contracting with different typologies of contracts and with different clauses within the standard contracts agreed at the national level by the national workers unions and the national business associations. This, by lateral monopolization of the labor market, in which the government interferes with ad hoc fiscal incentives, puts serious obstacles to the reduction in the employment and to the increase

members is given in the review of the literature of Caputo and Forte (2016, pp.109-152), and the contributions to the club government model in particular relation to the EU are given in Wohlgemuth and Brandi (2007, pp. 159-180) and Feld (2014). 


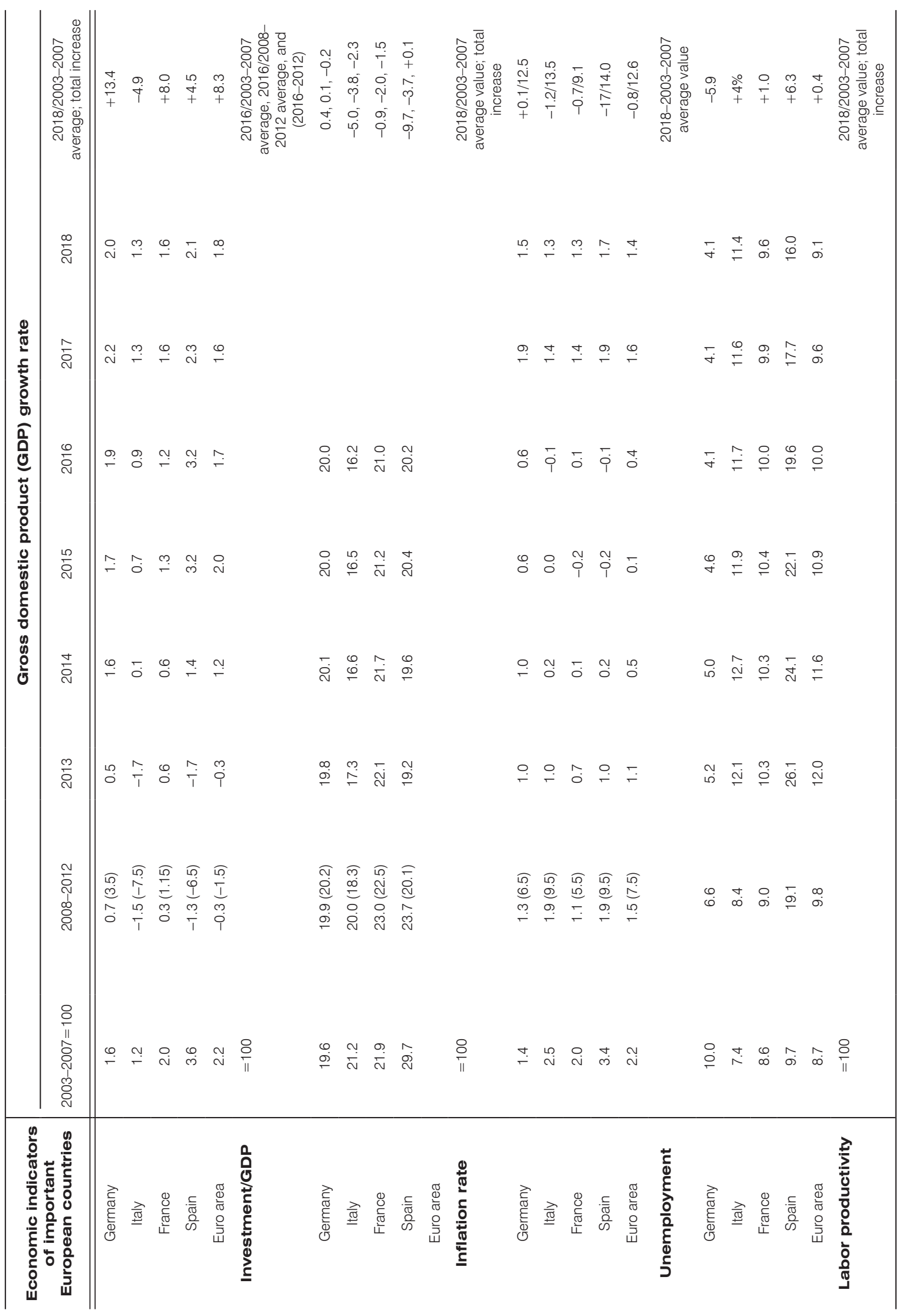

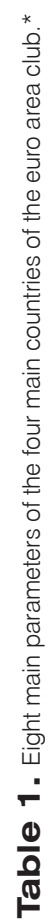




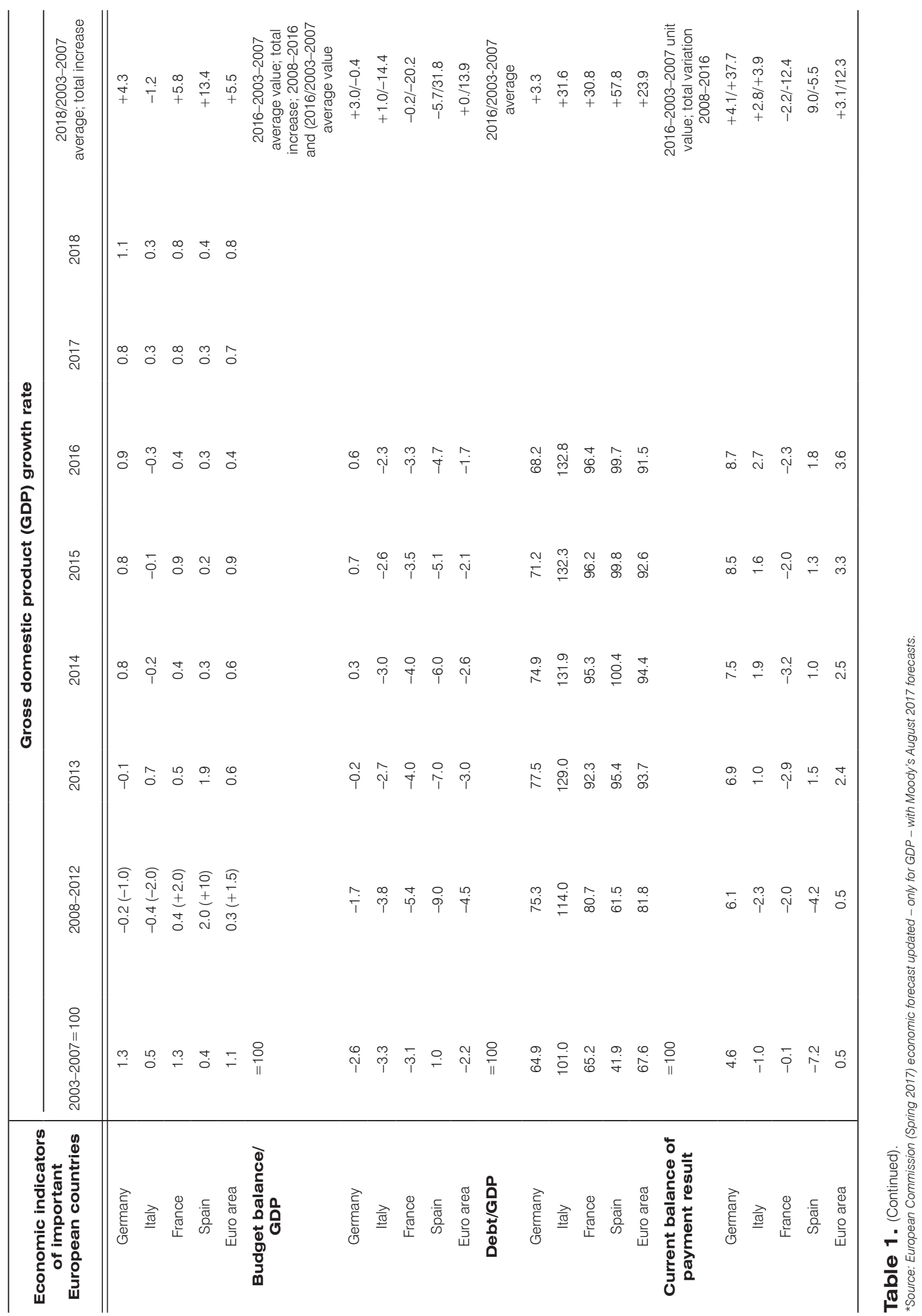


in productivity. Clearly, it implies a political economy of public interventions not to conform to the market, contrary to Röpke's and Einaudi's free competition model.

For the capital market, the business enterprises, and the goods and services market in the EU treaty, there are principles of free movement and free establishment. But the laws and regimes of the capital and business taxation greatly differ from country to country, with some countries such as Ireland, the Netherland, and Luxembourg practicing regimes that artificially attract capital, business, and trade by allowing forms of tax subsidies and avoidance tolerated by the EU (the reflections of Einaudi's and Röpke's theory of conform interventions are given in Einaudi [1937, pp.277-289] and Einaudi [1942]).

\subsection{Specifically, as for the monetary and fiscal policies, where national divergences of preferences do persist}

The principle of monetary stability represents a substantial element already of Eucken's rules the good government; ${ }^{2}$ consequently, also Röpke (Röpke's monetary policy principles are given in Röpke [1936, 1947, pp.57-71, pp.242-253, 1957] and Gregg [2010]), Einaudi (Einaudi' quantitative theory of monetary stability is given in Einaudi [1927, pp.74-90, 1929, pp.505-23, 1930, pp.227-261, 1990]) and Forte [2009, pp.271-301]) perceive it as a central rule for Europe. The prohibition for the central bank of financing their issuance of new public debts corresponds to the principles of the fathers of the EU original chart.

However, the meaning of monetary stability, as for euro, is still unclear and controversial. For a long period, European Central Bank (ECB) applied asymmetrically the monetary stability principle against inflation and not against deflation. The deflationary effects of the monetary policy and of the rate of exchange of euro with the other currencies, for most euro countries, were aggravated by the rigidities of the labor market and miss-behaviors of the banks. As there is not a unique banking system, the mechanism of transmission of the monetary policy works imperfectly. But after some delay, the nonconventional monetary policy adopted by the ECB under Mario Draghi has received the approval also from the staunch defend-

2 Eucken monetary principles based on a strong connection between the money supply and the reserve in gold as monetary commodity are given in Eucken (1923); Eucken (1925, 1929); Eucken (1928, pp. 120-123); Boese (1929, pp.287-305); Eucken (1951, pp.69-82); and Hunold (1951, pp.134-183). A critical discussion of Eucken' and Ordo's monetary principles is given in Feld et al. (2015). ers of the Bundesbank tradition (Feld et al. 2015). Its application has had robust positive effects for the eurozone recovery.

However, it can be seen that the dualistic situation has persisted in the eurozone, signaling that its construct is incomplete. Therefore, let us again reflect on Röpke's and Einaudi's concept of good government again.

The fiscal compact adopts the two fiscal principles of good government of Einaudi's and Röpke's budget balance as general rule and of deficits to take care of output gaps created by the cyclical fluctuations (the relevance of the output gap is given in Beqiraj et al. [2018]). However, in the application of the fiscal compact, the European Commission does not clearly distinguish between tax increases and reductions in spending, nor reductions in current or capital expenditures. It results in a trend of increase in the tax burden and reduction in public investment expenditures contrary to the Röpke's and Einaudi's good government principles, with perverse effects on growth and employment. Furthermore, while as for the fiscal policy to take care the output gap, Röpke and Einaudi would recommend the reduction in taxes and incentives to promote investments, and together with the removal of obstacles to the functioning of the market, the European Commission accepts public tax reductions and public spending to promote consumption. This deficit finance that corresponds to the neo-Keynesianism, in contrast to Einaudi and Röpke, while may bring the short-run popularity, hardly promotes the long-run growth (Forte and Magazzino 2011; Forte and Magazzino 2014; Fedeli 2012; Fedeli and Forte 2014; Fedeli et. al. 2014; Fedeli and Forte 2017.

The ECB set of nonconventional expansionary measures, while fostering GDP growth, has reduced the remuneration of savings near to zero, creating new problems for the budgets of the banks and unjust situations for the savers. These perverse effects, in the EMU area, arose, not because of the wrongness of these monetary recipes, but because of the anomaly of the existing fiscal rules, as for the EU budget. While the ECB, with the "quantitative easing" policy, can buy debt of the governments and public institution and cannot buy financial instruments of the EU budget, because the EU must balance its budget and cannot issue debts. Therefore, the EU cannot do an expansionary fiscal policy with the EU's own budget to avoid the fall of the interest rates to anomalous levels. The plans of public-private (PP) initiative of the EU unapplied, because of their great complexity, could be launched by a zero cost financing, if the EU was allowed to sell ad hoc unredeemable financial instruments to the ECB with zero interest rates. 
If the rule of the budget balance corrected for the output gap was allowed for the EU budget, the monetary seigniorage thus exerted would be that of the government of the club acting for the whole community. Combating deflation and unemployment, promoting growth, and avoiding the anomalous fall of the interest rate close to zero are according to the two principles of subsidiarity and interventions conform to the market of Röpke and Einaudi.

\section{Concluding remarks}

Clearly, a euro crisis exists; the explanation may be easily found considering the imperfections of the current architecture of EU and EMU, which - in principle could be completed along with the lines suggested earlier, which do not consist in creating a federation. It consists in completing the structure of the EU (and EMU) as market-conform club governments in a truly single European market system based on the liberal humane concept of civitas humana.

If there are obstacles to this objective, a proposal of more than one euro - according to some economists of the Ordo orthodoxy - could produce a better functioning currency union.

There would be no need to abolish the euro altogether. One may restore, with substantial improve-

\section{References}

Alberti L.B. (1432-34), I libri Della Famiglia (ed.1960), Bari. Aßländer M.S., Ulrich P., Einführung: Das Soziale der Sozialen Marktwirtschaft. Impressionen-Illusionen, In: Michael S.A., Ulrich P. (Eds.), 60 Jahre Soziale Marktwirtschaft: Illusionen und Interpretationen einer ordnungspolitischen Integrationsformel, Bern, 9-26, 2009.

Aßländer M.S., Wohlstand für alle? Die Soziale Marktwirtschaft vor der globalen Herausforderung, In: Aßländer M.S., Ulrich P. (Eds.), 60 Jahre Soziale Marktwirtschaft: Illusionen und Interpretationen einer ordnungspolitischen Integrationsformel, Bern, 223-255, 2009.

Beqiraj E., Fedeli S., Forte F., Public budgetary rules and GDP growth. An Empirical Study on OECD and European Countries. S Econ J, forthcoming, 2018.

Beqiraj E., Fedeli S., Forte F., La validità della regola del bilancio corretto per l'output gap e il rapporto Debito/PIL nell'analisi di Steve del 1952, e nella problematica attuale. Una verifica empirica sui paesi OCSE ed europei, Milano, 2017. ments, the mechanism of European Monetary System given to EBC a role of central bank of the two euro systems, where each member deposits parts of its reserves. In the first euro system, one of the systems in Germany, the rates of exchange among its members should absolutely be fixed as of now. In the second euro system, they could vary inside a band of fluctuation of each currency with the others. Each country would be responsible for assuring a credible budgetary policy, making possible the issuance, at reasonable conditions, of public debt in its own euro currency. Each country needs to have a flexible labor market and good rate of savings to remain in its fluctuation band, which are to be able to finance an investment that assures its competitiveness.

An apparent paradox thus emerges for the issue of the unique euro. A sound budgetary policy, a sustainable public debt, a flexible labor market, the respect for the saving, and property rights are a precondition both for remaining in the current imperfect euro system with a position strong enough to negotiate its improvement, according to the lines described earlier, and for exiting in a viable way to participate in another monetary club. If this is true, as it appears to the author, then the message is clear to complete the existing Europe with the ideals and the operational suggestions that arise from Röpke and Einaudi.

Boese F., (ed.), Wandlungen des Kapitalismus. Auslandanleihen. Kredit und Konjunktur, München, Leipzig, 1929.

Böhm F, Eucken W., Grossmann-Dörth H., The Manifesto of 1936, In: Peacock A., Willgerodt H. (Eds.), Germany's social market economy: origins and evolution, London, 15-26, 1936/1989.

Bruni L., L'impresa civile: Una via italiana all'economia di mercato, Milano, 2009.

Bruni L., Pelligra V., Economia come impegno civile: Relazionalità, benessere ed Economia di Comunione, Torino, 2002.

Bruni L., Zamagni S., Economia civile. Efficienza, equità, felicità pubblica, Bologna, 2004

Caputo M., Forte F., European Union and European monetary Union as clubs. The unsatisfactory convergence and beyond, Sudeuropa, Quadrimestrale di civiltà e cultura europea, 1, 109-152, 2016.

Carafa D (1470-74), Doveri del Re e del buon Principe, edited by Persico, Napoli, 1889. 
Di Battista F., Dalla tradizione genovesiana agli economisti liberali. Saggi di storia del pensiero economico meridionale, Bari, 1990.

Dietzfelbinger D., Soziale Marktwirtschaft als Imperativ. Alfred Müller-Armacks Stiltheorie, In: Aßländer M.S., Ulrich P. (Eds.), 60 Jahre Soziale Marktwirtschaft. Illusionen und Interpretationen einer ordnungspolitischen Integrationsformel, Bern, 95-117, 2009.

Einaudi L., II ritorno alla stabilità monetaria e la revisione dei rapporti creditizi, La Riforma Sociale, 38, 74-90, 1927.

Einaudi L., II contenuto economico della lira dopo la riforma monetaria del 21 dicembre 1927, La Riforma Sociale, 40, 505-23, 1929.

Einaudi L., Dei metodi per arrivare alla stabilità monetaria e se si possa ancora parlare di crisi di stabilizzazione della lira, Riforma Sociale, 41, 227-261, 1930.

Einaudi L., Delle origini economiche della grande guerra, delle crisi e delle diverse specie di piani, Rivista di Storia Economica, 2, 277-289, 1937.

Einaudi L., Economia di concorrenza e capitalismo storico. La terza via fra i secoli XVIII e XIX, In: Rivista di Storia economica, re-edited as Luigi Einaudi (2014), La civitas humana di Wilhlem Röpke, in Francesco Forte and Flavio Felice (Eds.), Il liberalismo delle regole, Genesi ed eredità dell'economia sociale di mercato, Soveria Mannelli, 185-225, 1942.

Einaudi L., La guerra e l'unità europea, Milano, 1948.

Einaudi L., Lezioni di politica sociale, Torino, 1949.

Einaudi L., II buon governo. Saggi ei economia e di politica (1897-1954), Bari, 1954.

Einaudi L., Prediche inutili, Torino, 1962.

Einaudi L., II mestiere della moneta, Torino, 1990.

Erhard L., Wohlstand für alle, Düsseldorf, 1957.

Eucken W., Kritische Betrachtungen zum deutschen Geldproblem, Jena, 1923.

Eucken W., Das Internationale Währungsproblem. Ein Überblick, Berlin, 1925.

Eucken W., Auslandsleihen, Magazin der Wirtschaft, 1, 120-123, 1928.

Eucken W., Kredit und Konjunktur, In: Boese F., (Ed.), Wandlungen des Kapitalismus. Auslandanleihen. Kredit und Konjunktur, München, 287-305, 1929.

Eucken W., Das ordnungspolitische Problem. ORDO, Jahrbuch für die Ordnung von Wirtschaft und Gesellschaft, 56-90, 1948.

Eucken W., Die Währungspolitik und ihre Konsequenzen, In: Eucken W. (Ed.), Unser Zeitalter der Mißerfolge. Fünf Vorträge zur Wirtschaftspolitik, Tübingen, 45-58., translation in English as Eucken W., 1951, Monetary policy and its consequences, In: Eucken W. (Ed.), This unsuccessful age or the pains of economic progress, London, 69-82, 1951.

Eucken W., Deutschland vor und nach der Währungsreform, In: Hunold A.,(Ed.), Vollbeschäftigung, Inflation und Planwirtschaft, Zürich, 134-183, 1951.

Eucken W., Grundsätze der Wirtschaftspolitik, Tübingen, 1952.

Fedeli S., Forte F., Public Debt and unemployment growth: the need of new fiscal-monetary rules. Evidence from OECD countries, Econ Politica, 3, 399-427, 2012.

Fedeli S., Forte F., Deficits, tax burden and unemployment, In: Forte F., Mudambi R., Navarra M. (Eds.), Handbook of alternative theories of public economics, Edward Elgar Publishing, Cheltenham, 116139, 2014.

Fedeli S., Forte F., Ricchi O., The long term negative relation between public deficit and structural unemployment: an empirical study of OECD countries (1980-2009), Atl Econ J, 43, 39-54, 2014.

Fedeli S., Forte F., The long term effects of Government budget constraints on GDP growth: an Empirical Study on OECD Countries (1980-2009), In: Bartolomeo G.D., Saltari E. (Eds.), Theoretical foundations of macroeconomic policy, Growth, Productivity and Public Finance, London, 295-321, 2017.

Feld L.P., James Buchanan's theory of federalism: from fiscal equity to the ideal political order, Freiburg Discussion Papers, No. 06/14, 2014.

Feld L.P., Köhler E., Nientiedt D., Ordoliberalism, pragmatism and the Eurozone crisis: how the German tradition shaped economic policy in Europe, Freiburg Discussion Papers, No. 04/15, 2015.

Felice F., Persona, istituzioni e mercato. La persona nel contesto del liberalismo delle regole, Soveria Mannelli, 2013.

Felice F., Prefazione, In: Röpke W., Al di là dell'offerta e della domanda. Verso un'economia umana, Soveria Mannelli, 2014.

Felice F., Prefazione, In: Röpke W., Civitas Humana. I problemi fondamentali di una riforma sociale e economica, Soveria Mannelli, 2016.

Forte F., L'optimum economico e la teoria del punto critico nel pensiero di Emanuele Sella, In: Vaudano M., (Ed.), La figura e l'opera di Emanuele Sella, Biella, 1999.

Forte F., Il liberalismo sociale di Wilhelm Röpke, in Ideazione, 4, 2001, reedited with small changes as Forte F., Einaudi e Röpke, Interventi conformi ed economia sociale di mercato, In: Forte F. (Ed.), L'economia liberale di Luigi Einaudi, Firenze, 223-251, 2009a. 
Forte F., Economia dei mercati globali e governo sovranazionale secondo Luigi Einaudi, in II Pensiero Economico Italiano, 15, 21-49, 2007, re-edited in Forte F., L'economia liberale di Luigi Einaudi, Firenze, 303-342, 2009b.

Forte F., L'economia liberale di Luigi Einaudi, Firenze, 2009c.

Forte F., The architecture of Luigi Einaudi good government, In: Heritier P., Silvestri P. (Eds.), Good government, governance, human complexity, Luigi Einaudi's Legacy and Contemporary Societies, Firenze, 2012.

Forte F., Felice F., Forte C., L'economia sociale di mercato e i suoi nemici, Soveria Mannelli, 2012.

Forte F., Felice F. (Eds.), Il liberalismo delle regole, Genesi ed eredità dell'economia sociale di mercato, Soveria Mannelli, 2016

Forte F., Magazzino C., Optimal size government and economic growth in EU countries, Economia Politica, 28, 295-321, 2011.

Forte F., Magazzino C., Optimal size of governments and optimal ratio between current and capital expenditure, In: Forte F., Mudambi R., Navarra P.M. (Eds.), Handbook of alternative theories of public economics, Cheltenham, 342-367, 2014.

Goldschmidt N., Alfred Müller-Armack and Ludwig Erhard Social Market Liberalism, Freiburg Discussion Papers of Constitutional Economics, No. 04/12, 2004

Goldschmidt N., Die Geburt der Sozialen Marktwirtschaft aus dem Geiste der Religion - Walter Eucken und das soziale Anliegen des Neoliberalismus, In: Aßländer M.S., Ulrich P. (Eds), 60 Jahre Soziale Marktwirtschaft. Illusionen und Interpretationen einer ordnungspolitischen Integrationsformel, Bern, 27-44, 2009.

Goldschmidt N., Wohlgemuth M., Social market economy: origins, meanings and interpretations, Const Political Econ, 19, 261-276, 2008a.

Goldschmidt N., Wohlgemuth M., Grundtexte zur Freiburger Tradition der Ordnungsökonomik, Tübingen, 2008b.

Gregg S., Wilhelm Röpke political economy, Cheltenham, 2010.

Heritier P., Silvestri P., Good government. Governance, human complexity, Luigi Einaudi's Legacy and Contemporary Societies, Firenze, 2012.

Hunold A., (ed.), Vollbeschäftigung, Inflation und Planwirtschaft, Erlenbach-Zürich, 1951.

Krienke M., Rosmini as the idea-historic predecessor of social market economy, liberal remarks to some actual interpretations of the philosophy of right.
A series of five video lectures by the Chair Antonio Rosmini, Lugano, 2014.

Mingardi A., A sphere around the person: Antonio Rosmini on Property, J Markets Moral, 7, 63-97, 2004.

Müller-Armack A., Wirtschaftslenkung und Marktwirtschaft, München, 1946.

Müller-Armack A., Wirtschaftsordnung und Wirtschaftspolitik. Studien und Konzept zur Sozialen Marktwirtschaft und zur Europäischen Integration, Bern and Stuttgart, 1976.

Nicholls A.J., Freedom with responsibility: the social market economy in Germany, 1918-1963, Oxford, 1994.

Peacock A., Willgerodt H., German liberalism and economic revival, In: Peacock A., Willgerodt $\mathrm{H}$. (Eds.), Germany's social market economy: origins and evolution, London, 1989a.

Peacock A., Willgerodt H., Germany's social market economy: origins and evolution, London, 1989b.

Pii E., Antonio Genovesi. Dalla politica economica alla 'politica civile', Firenze, 1984.

Röpke W., Crisis and cycles, adapted from the German and revised by V.G. Smith, London, 1936.

Röpke W., Die Gesellschaftskrisis der Gegenwart, Zürich, translated in English as Wilhelm Röpke (1950), The social crisis of our time, Chicago, 1942.

Röpke W., Civitas Humana. Grundfragen der Gesellschafts-und Wirtschaftsreform, Erlenbach-Zürich, translated as Röpke W., 1960, A humane economy. The Social framework of free market, Chicago, 1944.

Röpke W., Civitas Humana. I problemi fondamentali di una riforma sociale e economica, Soveria Mannelli, 2016.

Röpke W., Offene und Zurückgestaute Inflation, Kyklos, 1, 57-71, 1947.

Röpke W., Repressed inflation, Kyklos, 1, 242-253, 1947.

Röpke W., Maß und Mitte, Erlenbach-Zürich, 1950.

Röpke W., Internationale Ordnung - Heute, ErlenbachZürich, translated as Wilhelm Röpke (1959), International order and Economic Integration, Dordrecht, 1953.

Röpke W., Welfare, freedom and inflation, London, 1957.

Röpke W., Jenseits von Angebot und Nachfrage, Düsseldorf, 1958/2009.

Röpke W., European economic integration and its problems, Modern Age Q Rev, Summer, 231-244, 1966. 
Rosmini A., The philosophy of politics, Vol. 1 The summary cause for the stability or downfall of human societies; vol. 2 Society and its purpose, Durham, 1994.

Rosmini A., The philosophy of right. Vol. 1 (1993). The essence of right, vol. 2 (1993), Rights of the individual, vol. 3 (1995). Universal social right, Vol. 4 (1995), Rights in God's Church, vol. 5 (1995) Rights in the family, vol. 6 (1996), Rights in civil society, Durham, 1993-1996.

Sacchi, B., (Platina II) (1461/1944), De optimo cive, edited by Felice Battaglia, Bologna, 1944.

Sacchi B., (Platina II) (1471/1979), De principe, edited by Giovanni Ferraù, Palermo, 1979.

Silvestri P., The ideal of good government in Luigi Einaudi's thought and life between law and freedom, In: Heritier P., Silvestri P. (Eds.), Good government, governance, human complexity. Luigi
Einaudi's Legacy and Contemporary Societies, Firenze, 57-100, 2012.

Tomatis F., Verso la città divina. L'incantesimo della libertà in Luigi Einaudi, Torino, 2011.

Vanberg V.J., The Freiburg school: Walter Eucken and ordoliberalism, Freiburg Discussion Papers on Constitutional Economics, No. 04/11, 2004.

Venturi F., Settecento riformatore, Vol. 1, Torino, 1969.

Vaudano M., La figura e l'opera di Emanuele Sella, Biella, 1999.

Villari L., II pensiero economico di Antonio Genovesi, Firenze, 1959.

Wohlgemuth M., Brandi C., Strategies of flexible integration and enlargement of the European Union. A club-theoretical and constitutional economics perspective, Freiburg Discussion Papers No. 06/07, 2007. 